\title{
SARANA PENGEMBANGAN KOMUNITAS PENGRAJIN FURNITUR KLENDER YANG BERBASIS PADA KESEHATAN LINGKUNGAN KERJA PENGRAJIN
}

\author{
Jason Nathanael ${ }^{1)}$, Rudy Surya ${ }^{2)}$ \\ 1)Program Studi S1 Arsitektur, Fakultas Teknik, Universitas Tarumanagara, jasonnath98@gmail.com \\ 2) Program Studi S1 Arsitektur, Fakultas Teknik, Universitas Tarumanagara, rudys@ft.untar.ac.id
}

Masuk: 20-01-2021, revisi: 21-02-2021, diterima untuk diterbitkan: 26-03-2021

\begin{abstract}
Abstrak
Cara berhuni seseorang, sekelompok orang, dan suatu komunitas di satu kawasan bergantung pada proses berhuni mereka. Proses berhuni dibentuk dari pengalaman, kejadian, dan pemecahan masalah di masa lampau. Akumulasi dari proses berhuni yang dialami komunitas di suatu kawasan membentuk citra kawasan. Citra kawasan yang terbentuk dari cara berhuni ini juga terjadi di kawasan Klender, Jakarta Timur. Citra kawasan yang terbentuk adalah Klender sebagai pusat industri furnitur bagi Kota Jakarta dan sekitarnya. Walaupun memiliki status sebagai pusat industri furnitur, tidak juga terlepas dari berbagai masalah. Mulai dari tenaga kerja yang kurang menguasai teknologi modern, lingkungan kerja yang buruk bagi kesehatan pernafasan pengrajin, dan sektor promosi yang kurang berkembang. Melihat masalah dan kebutuhan yang ada, dapat dilakukan pengembangan industri furnitur yang ada di Kelurahan Klender. Pengembangan industri furnitur ini mencakup solusi untuk memajukan industri menatap masa depan. Pendekatan desain yang dilakukan pada penelitian ini adalah melalui metode desain pragmatis, yaitu desain yang berorientasi pada manfaat langsung yang dapat dihasilkan. Tentu manfaat yang ingin dihasilkan adalah fasilitas yang dapat meningkatkan kemampuan pengrajin furnitur dan yang memiliki lingkungan kerja yang sehat. Fasilitas ini mencakup pelatihan dan pendidikan tenaga kerja dalam hal desain, produksi, dan teknologi. Selain itu, menciptakan lingkungan kerja dalam hal ini sirkulasi udara yang sehat bagi pengrajin. Selain itu, menciptakan sistem pembuangan serbuk kayu dan filter udara untuk menciptakan lingkungan kerja yang sehat di area produksi. Tujuan dari pengembangan ini tentunya untuk meningkatkan kualitas berhuni masyarakat dalam hal pekerjaan mereka di bidang industri furnitur supaya dapat bersaing di pasar domestik maupun mancanegara di masa pandemi covid ini dan sesudahnya.
\end{abstract}

\section{Kata kunci : Industri furnitur; Klender; Pengrajin}

\begin{abstract}
The way of a person, a group of people, and a community to dwell in certain area depends on their settlement process. The process of living is formed by experiences, events, and problem solving in the past. The accumulation of the habitual process experienced by a community in an area forms an image of the area. The image of the area formed by this way of living also occurs in Klender area, East Jakarta. The image formed is furniture industry center for Jakarta and the cities nearby. Although having an image of the furniture industry center, there are still many problems in the industry process. Starting from the problem with the workforce, the technology, worker's respiratory health, until how to promote the product. Seeing the existing problems and needs, we can find a solution by human development in the furniture industry. The development of furniture industry includes solutions to advance the
\end{abstract}


industry towards the future. The design approach used in this project is pragmatic design method that is oriented towards the direct benefits which can be seen. Of course the direct benefits are facilities that can improve the human resource in the modern furniture industry with the knock down industry system. Also creating a healthy working environment for the craftsmen. These facilities include training education in design, production and technology. In addition, it creates a healthy working environment, in this case a healthy air circulation for the craftsmen. The healthy air circulation system mentioned before is creating dust collector system and air filter system in the production area. The purpose of these ideas are of course to improve the quality of inhabitants of the community in terms of their work in the furniture industry so that they can compete in the domestic and foreign markets during the Covid pandemic and afterwards.

Keywords: Furniture industry; Klender; Carpenter

\section{PENDAHULUAN}

\section{Latar Belakang}

Kelurahan Klender merupakan kawasan dengan citra industri furniture yang sudah terkenal sejak tahun 1960 an. Citra industri furnitur yang melekat di kawasan ini terbentuk dari kebiasaan, tradisi dan cara berhuni penghuninya. Industri furnitur di kawasan Klender ini didominasi oleh industri skala kecil dan menengah. Walaupun memiliki citra industri furnitur kecil dan menengah yang sudah melekat sejak lama, industri di kawasan ini tidak lepas dari berbagai permasalahan. Mulai dari pemakaian teknologi yang kuno/tidak modern, lingkungan kerja pengrajin yang tidak mendukung bagi kesehatan pernafasan mereka, dan sector promosi industri furnitur di Kawasan ini yang kurang dilirik oleh mayoritas konsumen furnitur atau hanya sebagian orang saja yang mengetahui produk-produk dari industri furniture Klender.

Melihat berbagai permasalahan ini, pengembangan komunitas pengrajin furnitur dengan adanya pelatihan perancangan furnitur dengan desain-desain terbaru, pelatihan dengan sistem modern, dan pengembangan sektor promosi yang terinteregasi dengan aktivasi ruang publik sehingga dapat menarik pengunjung dating dan menghidupkan Kawasan dapat menjadi solusi. Dengan adanya sarana pengembangan ini, maka diharapkan industri kecil dan menengah furniture Klender dapat bersaing dan unggul karena hasil produknya dan tenaga kerjanya.

\section{Rumusan Permasalahan}

a. Program ruang yang dapat meningkatkan kemampuan pengrajin furnitur dalam hal industri furnitur modern, khususnya knock down industry.

b. Desain lingkungan kerja para pengrajin furnitur skala kecil dan menengah yang kurang memperhatikan kesehatan mereka terlihat dalam desain bengkel furnitur di sekitar tapak yang tidak memiliki sirkulasi udara yang baik.

c. Tidak adanya ruang publik di sekitar tapak yang dapat menimbulkan aktivitas untuk menghidupkan kawasan sehingga dapat membantu sektor promosi furnitur juga sector UMKM lainnya.

\section{Tujuan}

a. Mendesain program ruang yang dapat meningkatkan kemampuan pengrajin furniture dalam hal industri modern, khususnya knock down industry.

b. Menciptakan lingkungan fasilitas pengembangan industri furnitur yang sehat bagi pengrajin furnitur dengan sistem sirkulasi udara yang baik.

c. Menciptakan ruang publik untuk menciptakan aktivitas yang bersifat komunal di tapak supaya dapat menghidupkan kawasan dan dapat membantu sektor promosi furnitur juga sektor UMKM lainnya. 


\section{KAJIAN LITERATUR}

\section{Teori Mengenai Dwelling}

Menurut Martin Heidegger (1971:1) dalam tulisannya yang berjudul "Building Dwelling Thinking", kita tidak berhuni karena adanya bangunan, namun kita mendirikan bangunan karena kita berhuni. Karakter fundamental dari berhuni adalah menjaga dan melestarikan sehingga kita menciptakan ruang di mana adanya rasa aman di lingkungan yang kita buat. Berhuni bukan hanya di definisikan sebagi rumah, namun juga sebagai ruang segala aktivitas manusia. Maka ruang-ruang ciptaan ini dasarnya beradaptasi dari cara berhuni penggunanya.

Michel De Certeau (1980:10) dalam bukunya "The Practice of Everyday Life" mengatakan bahwa neighborhood / suatu lingkungan bertetangga atau yang dapat disebut sebagai kawasan mempunyai citra yang muncul atau berasal dari karakter para penghuninya. Karakter dan kebiasaan masing - masing individu yang berhuni di suatu kawasan yang sama akan membentuk suatu cara berhuni yang kolektif dan menciptakan suatu citra kawasan.

\section{Teori Klaster Industri}

Menurut teori Michael Porter (1998) mengenai klaster industri, Konsentrasi geografis dari perusahaan-perusahaan dan institusi-institusi yang saling berhubungan dalam wilayah tertentu, biasanya memproduksi barang yang heterogen dan memiliki industri pendukung yang sama. Misal untuk klaster industri furniture memiliki industri pendukung berupa peralatan seperti kunci lemari, engsel, dll.

\section{Profil Kelurahan Klender dan Sejarah Industri Furnitur}

Klender adalah kelurahan di wilayah Kecamatan Duren Sawit, Jakarta Timur. Kawasan itu berbatasan dengan Jatinegara Kaum di sebelah utara, Cipinang Muara di barat, dan Pondok Kopi di timur, dan Pondok Bambu di bagian selatannya. Klender terkenal karena klaster industri furnitur nya. Sejarah Klender tumbuh sebagai pusat pengrajin mebel kayu jati rumahan itu dimulai pada tahun 1950. Cikal bakalnya dari daerah Jatinegara Kaum dan Pulo Kambing, yang banyak pengusaha kecap. Pengusaha itu memesan tahang(tempat air) dari kayu jati untuk tempat kecap, kepada penduduk sekitar. Lambat laun, jumlah pemesan semakin banyak dan merangsang kreativitas para pengrajin kayu untuk mengembangkan bentuk produk lain. Setelah itu, mereka mulai mengembangkan kemampuan mereka untuk dapat membuat perabotan rumah.

\section{Klaster Industri Furnitur Klender}

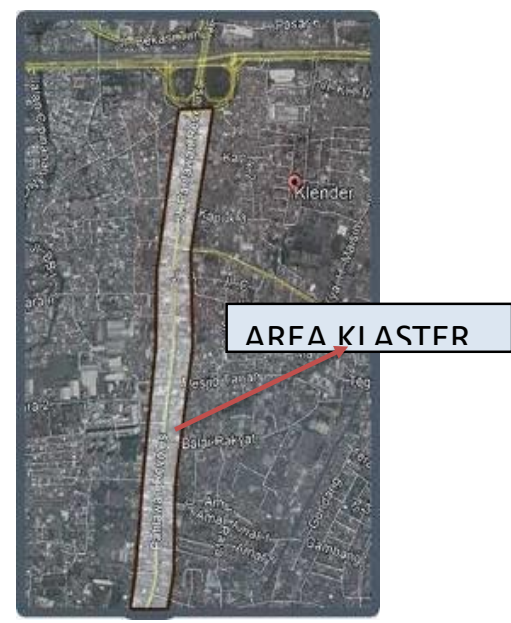

Gambar 1. Peta Klaster Industri Sumber : Penulis, 2020 
Klaster didefinisikan sebagai perusahaan-perusahaan yang sejenis(sama) atau yang saling berkumpul dalam suatu batasan geografis tertentu(Enright, 1998).

Klaster industri furnitur yang berkembang di kawasan Klender ini berpusat di sepanjang Jalan Pahlawan Revolusi sampai ke Banjir Kanal Timur di bagian selatan jalan. Di dalam klaster ini terdapat pelaku industri furnitur yang memproduksi barang-barang yang berasal dari bahan baku kayu. Di sepanjang jalan ini terdapat toko, gudang, dan bengkel furnitur yang membentuk sebuah klaster perdagangan dan industri. Umumnya, terdapat 2 segmentasi pasar, yaitu industri skala kecil dan menengah dengan industri skala besar.

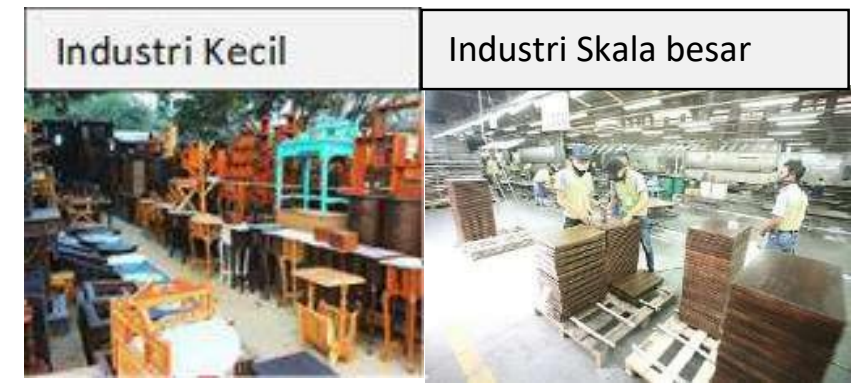

Gambar 2. Industri furniture skala kecil

Sumber : Pustaka dunia, 2019
Gambar 3. Industri furniture skala kecil

Sumber : Radar Surabaya, 2020

\section{Proses Industri Furnitur Secara Umum dan Sistem Knock Down}
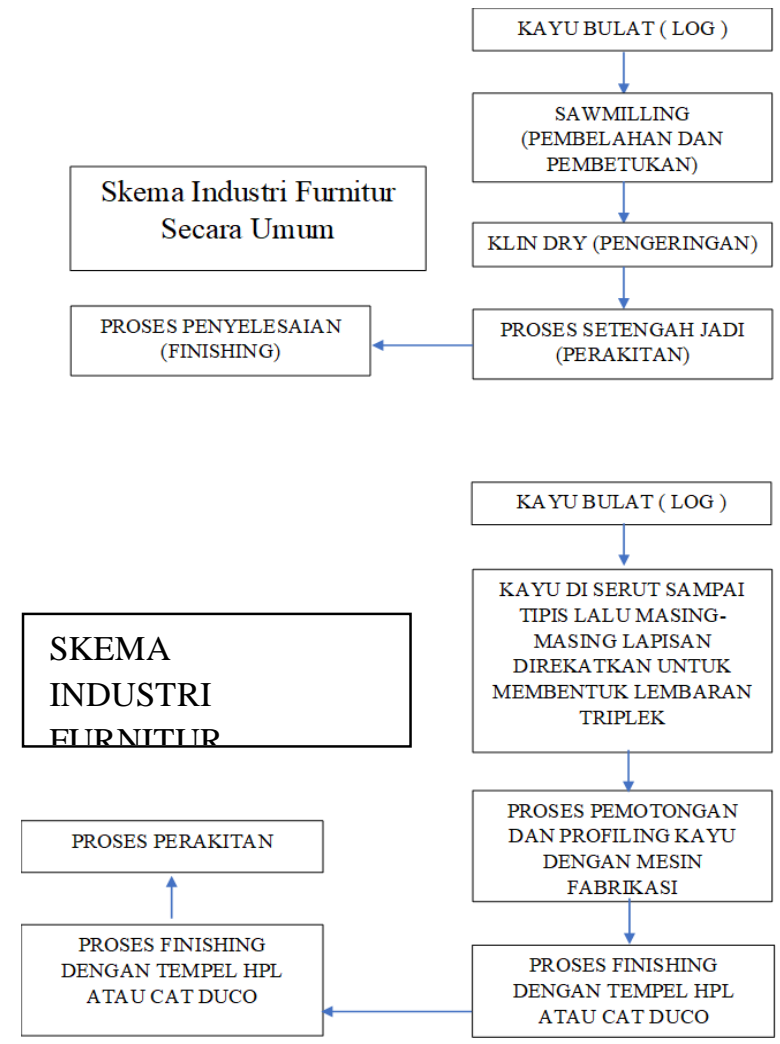

Gambar 4. Skema Industri Furnitur

Sumber : Penulis, 2020 


\section{Teori Ruang Publik}

Menurut Stephen Carr (1992), terdapat tiga kategori kualitas yang dibutuhkan oleh ruang publik ;

1. Responsif, ruang publik di desain sesuai dengan kebutuhan pengguna.

2. Demokratis, menjunjung nilai kebebasan untuk semua kalangan melakukan aktivitas/inklusif. Pengguna dapat mengutarakan pendapatnya secara bebas di ruang ini, namun juga terdapat batasan-batasan karena adanya toleransi nilai di antara masingmasing pengguna ruang publik.

3. Bermakna, mencakup hubungan emosional antara ruang dan penggunanya.

\section{Kesehatan Lingkungan Kerja Dengan Teknik Passive Cooling Cross Ventilation}

Dalam mendesain lingkungan kerja bagi pengrajin furniture, maka dibutuhkan kualitas komposisi udara yang bebas bahan beracun akibat residu industri furniture seperti cat, lem, dll. Juga memiliki sirkulasi udara yang baik dan lancar. Maka, desain passive cooling dengan teknik cross ventilation sangat dibutuhkan.
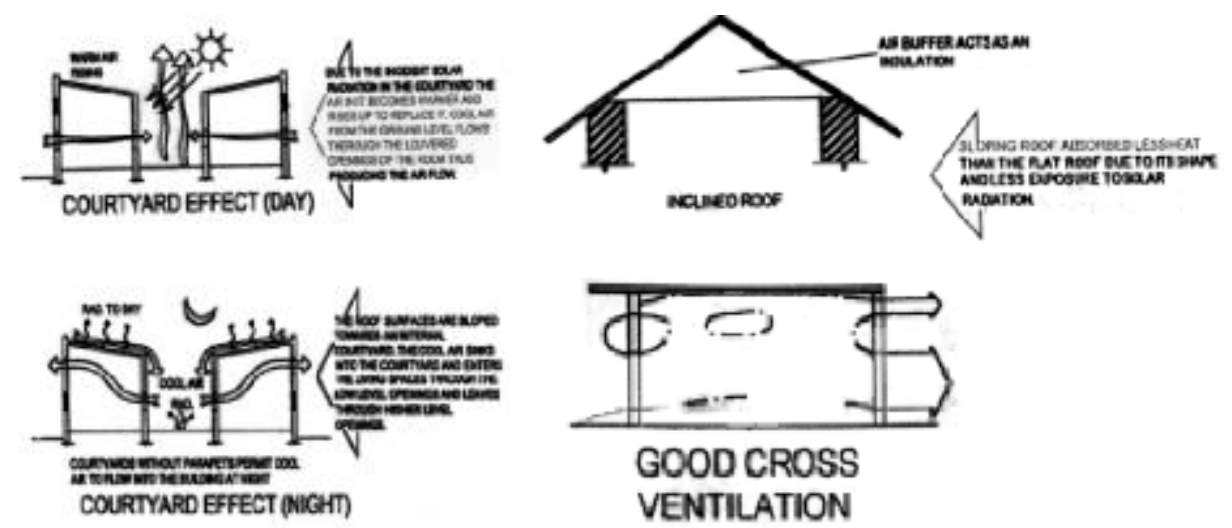

Gambar 5. Teknik Pendinginan udara secara pasif

Sumber : Climatic Responsive Energy Efficient Passive Techniques Building, 2003

Pertama, dengan adanya courtyard effect yang berarti udara panas dari dalam ruangan yang memiliki temperatur tinggi di transfer menuju courtyard dan dengan cepat udara panas tersebut menguap ke atas pada siang hari. Pada malam hari, udara dingin dari luar ruangan masuk melalui courtyard ke dalam ruangan dan mengalir keluar menuju bukaan yang lebih tinggi. Lalu, factor yang berpengaruh terhadap sirkulasi udara adalah cross ventilation di tiap ruangan yang harus memiliki bukaan yang berbeda level ketinggian supaya udara dapat mengalir dengan baik di dalam ruangan.

\section{METODE}

Metode di penelitian ini memakai metode pragmatis berorientasi pada manfaat langsung yang dapat dihasilkan seperti menciptakan ruang-ruang yang nyaman sesuai dengan program ruang yang mendukung pelatihan industri furniture knock down. Melalui metode pragmatis ini, juga dilakukan pendekatan desain yang memperhatikan kesehatan lingkungan pengrajin furnitur. Pendekatan desain ini mengacu pada desain pasif dan desain aktif. Desain pasif yang dimaksud adalah dengan mendesain area courtyard dan area balkon hijau yang mengelilingi ruang dalam bangunan dengan tujuan supaya setiap ruangan mempunyai sirkulasi udara yang baik. Selain itu, untuk desain aktif menggunakan berbagai sistem buatan, yaitu sistem air filter pada area finishing furniture dan sistem pengumpul debu pada area potong furnitur. 


\section{DISKUSI DAN HASIL}

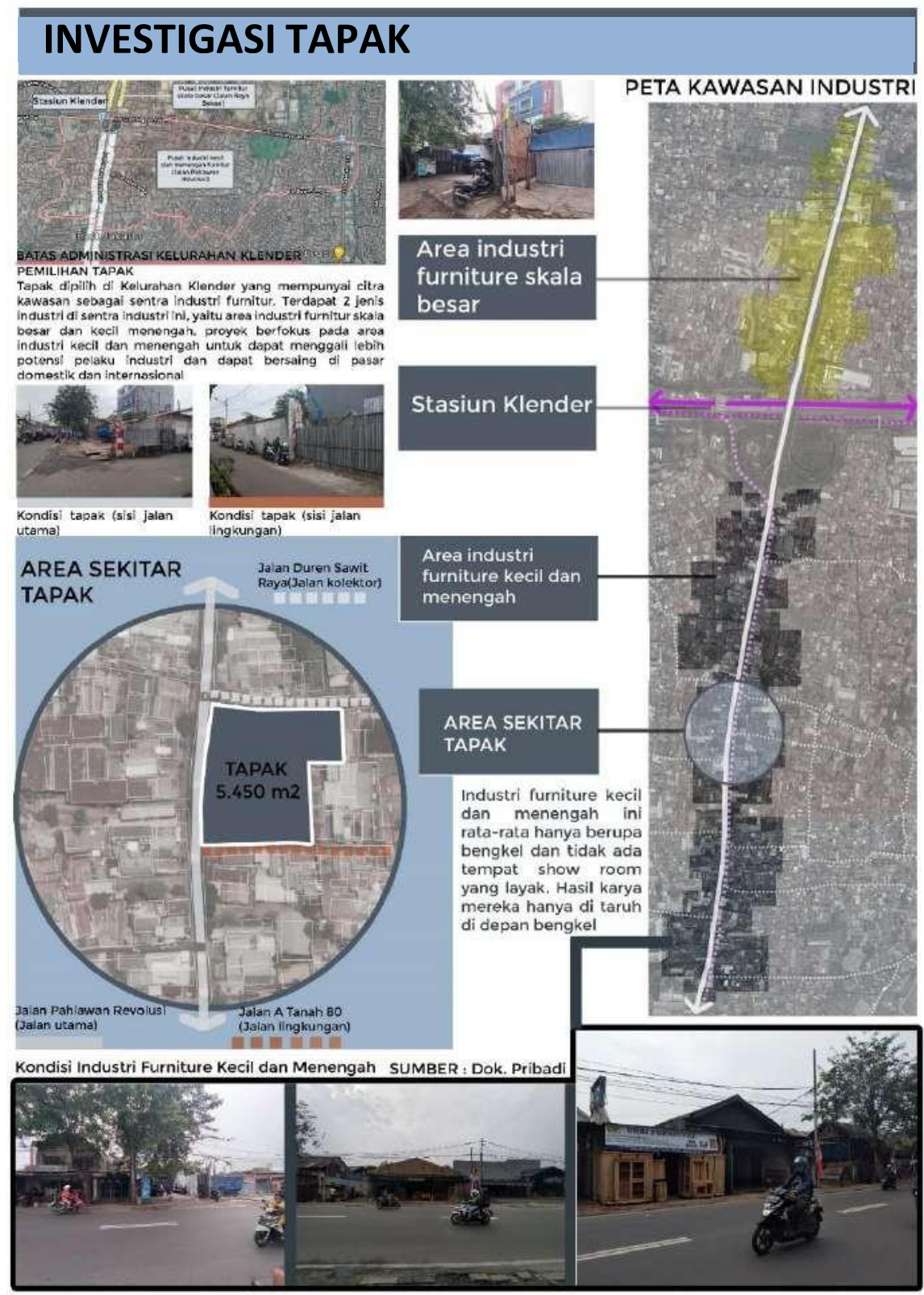

Gambar 6. Investigasi Tapak

Sumber : Penulis, 2020

Dapat dilihat dari dokumen foto survey bahwa jalan utama, yaitu Jalan Pahlawan Revolusi yang merupakan struktur jalan utama dari kawasan dapat dilalui motor dan mobil. Jalan utama hanya memiliki 2 lajur yang berlawanan arah dan tingkat kemacetan yang tinggi di pagi dan sore hari.

Dapat juga dilihat dari peta klaster industri furnitur yang ada di Kelurahan Klender terdapat pembagian area industri sesuai dengan skala masing-masing. Industri kecil dan menengah memiliki warna hitam dan industri skala besar memiliki warna kuning. Tapak terletak di area yang berwarna hitam, yaitu industri skala kecil dan menengah.

\section{Analisis Tapak}

Tapak memiliki luas $5.450 \mathrm{~m} 2$, berada di zonasi perkantoran, perdagangan, dan jasa dengan KDB : 50, KLB : 2, KB : 4, dan KDH : 30. Aktivitas di sepanjang Jalan Pahlawan Revolusi adalah berupa bengkel produksi furnitur yang mengolah bahan mentah menjadi bahan mentah 
menjadi bahan jadi atau bahan setengah jadi seperti lembaran triplek kayu menjadi bahan jadi. Tapak dekat dengan akses transportasi umum, yaitu Stasiun Klender dengan jarak tempuh kurang dari 500 meter dari tapak.

Tapak memiliki tiga muka untuk entrance yaitu melalui Jalan Pahlawan Revolusi(jalan utama), Jalan Duren Sawit Raya, dan Jalan A Tanah 80. Untuk jalan utama dan Jalan Duren Sawit Raya dapat dilalui oleh kendaraan mobil dan motor, sementara untuk Jalan $A$ tanah 80 hanya dapat dilalui oleh sepeda motor.
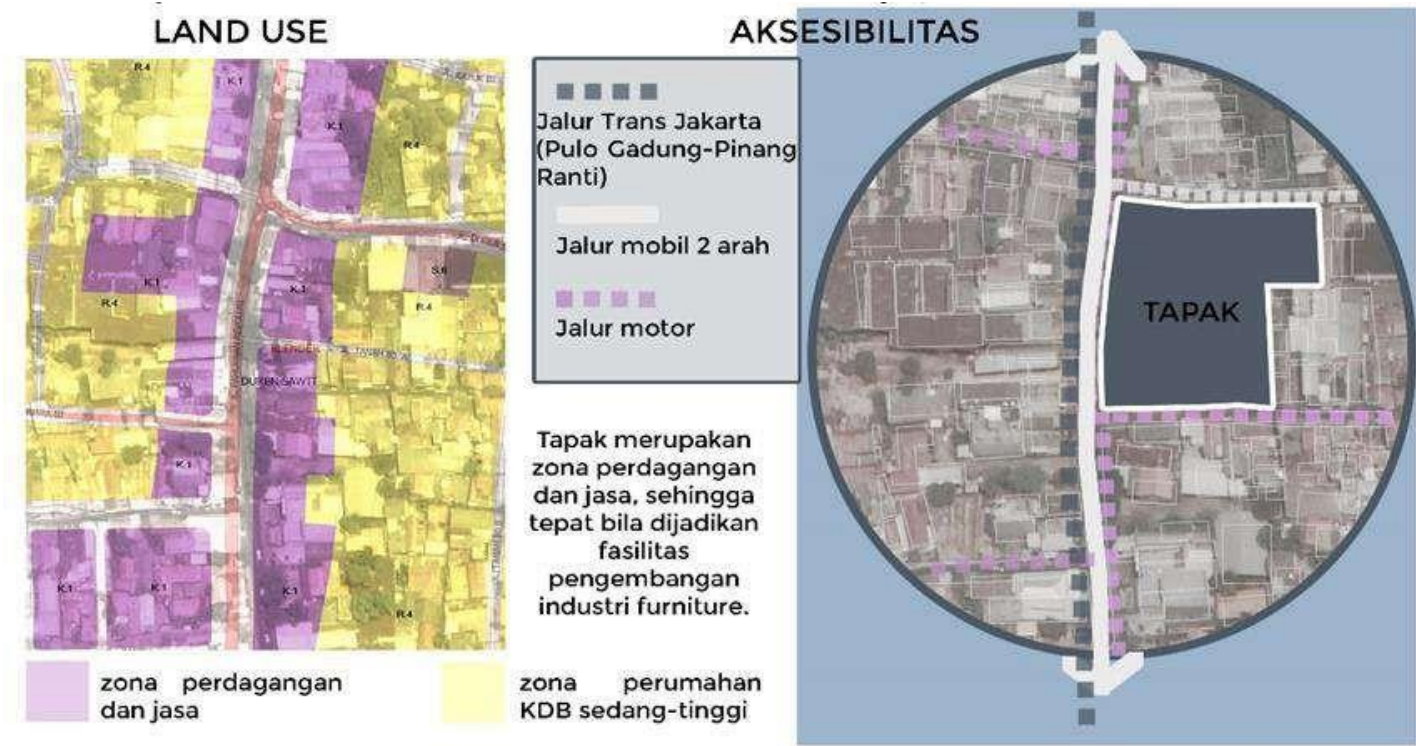

Gambar 7. Land Use dan Akesibilitas

Sumber : Penulis, 2020

Tapak terletak di layer pertama zonasi dari struktur jalan utama, Jalan Pahlawan Revolusi. Tapak dilalui Bus Transjakarta feeder menuju jalan arteri di utara tapak, yaitu Jalan I Gusti Ngurah Rai.

\section{Analisis Sintesis :}

a. Kurangnya ruang publik yang dapat merangkul komunitas pengrajin dan warga sekitar sehingga Kawasan menjadi hidup.

Sintesis : Mendesain suatu ruang publik yang dapat menjadi wadah bagi komunitas pengrajin furnitur dan warga sekitar untuk berinteraksi, bertukar inonvasi, dan dapat menghidupkan kawasan.

b. Dari pengamatan langsung ke sekitar tapak, dapat diketahui bahwa bengkel produksi furnitur di sekitar tapak tidak memiliki fasilitas showroom yang layak.

Sintesis : Mendesain showroom furnitur yang dapat menjadi satu kesatuan dengan area pedestrian, sehingga pengunjung dapat langsung meng akses menuju showroom.

c. Berdasarkan survey yang dilakukan, dapat diketahui bahwa di setiap bengkel produksi furnitur tidak memiliki sistem sirkulasi udara yang baik untuk membuang residu-residu hasil produksi seperti serbuk kayu, debu, dan cat.

Sintesis : Memastikan ruang-ruang produksi dan ruang pelatihan lainnya memiliki sirkulasi udara yang baik dan juga untuk ruang-ruang khusus seperti ruang potong dan ruang cat untuk diberikan fasilitas pertukaran udara seperti suplai udara segar ke dalam ruangan dan exhaust udara yang mengandung residu hasil produksi ke luar. 


\section{Konsep Perancangan Ruang Dalam}

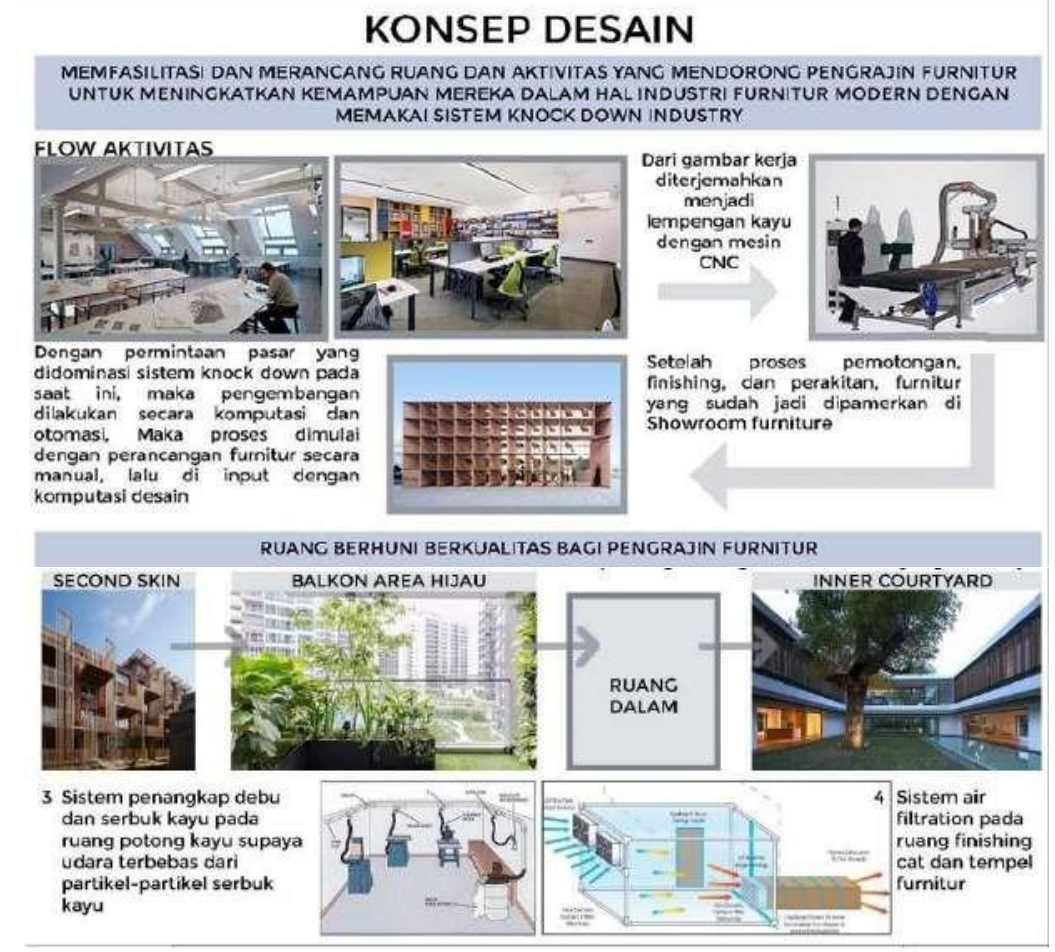

Gambar 8. Konsep Ruang Dalam

Sumber : Penulis, 2020

Konsep perancangan ruang dalam dari proyek ini berfokus pada penciptaan kualitas lingkungan yang sehat bagi para pengrajin furnitur yang berpotensi terpapar residu dari hasil produksi furnitur seperti debu, serbuk kayu, dan residu gas cat yang dapat merusak kesehatan pernafasan. Penciptaan sirkulasi udara yang baik ini ditunjukan dengan adanya desain area hijau berupa balkon yang menonjol dari bentuk dasar bangunan. Balkon area hijau ini berfungsi untuk menurunkan suhu udara yang masuk ke dalam ruangan dan juga sebagai filter polusi. Sehingga angin dari luar bangunan dapat masuk melalui second skin, lalu ter filter di balkon area hijau, masuk ke ruang dalam, dan keluar melalui inner courtyard

\section{Konsep Perancangan Ruang Luar}
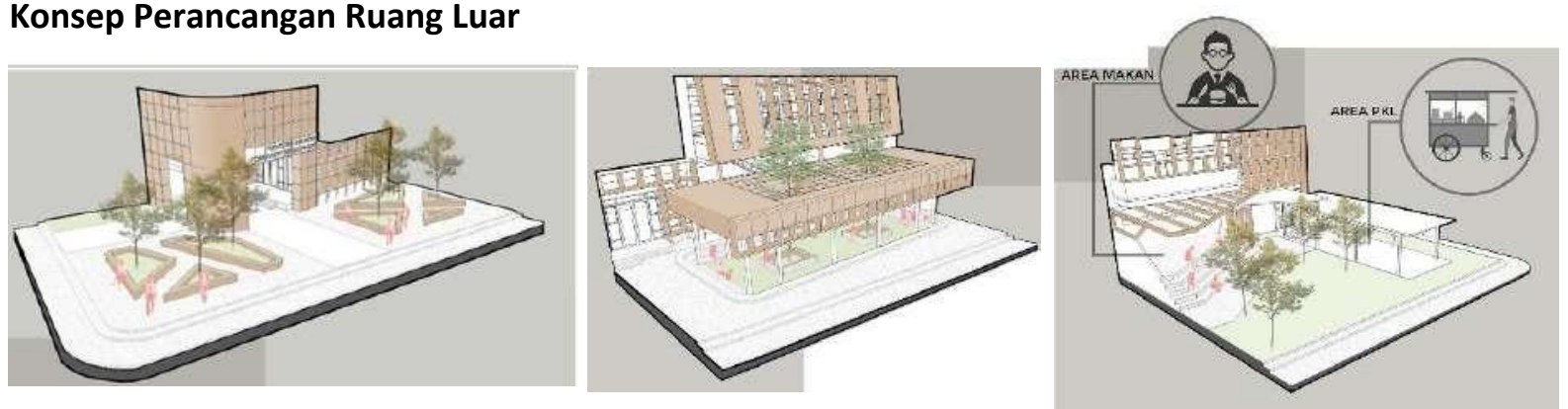

Gambar 9. Konsep Perancangan Ruang Luar

Sumber : Penulis, 2020

Pada lantai dasar terdapat area outdoor yang berfungsi sebagai ruang public dan komunitas. Ruang-ruang ini adalah plaza public sebagai transisi sebelum masuk ke entrance utama dan sebagai ruang publik untuk warga kota, lalu ada ruang komunitas di mana para pengrajin dan warga kota dapat berinteraksi, dan juga ada area makan outdoor yang memfasilitasi para UMKM untuk dapat berjualan. 


\section{Program Ruang}

PROGRAM RUANG

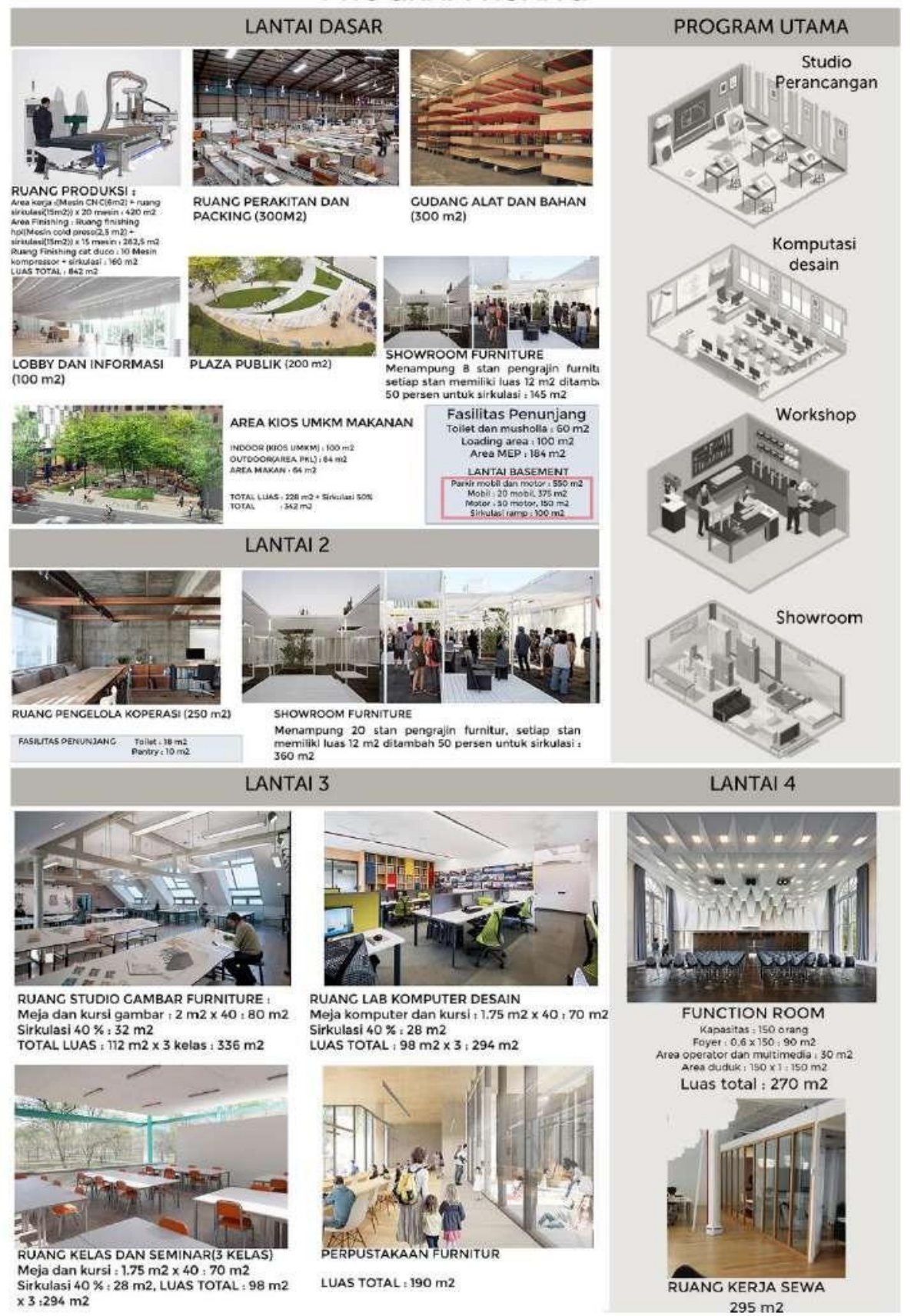

Gambar 10. Program Ruang

Sumber : Penulis, 2020 


\section{Denah perancangan}
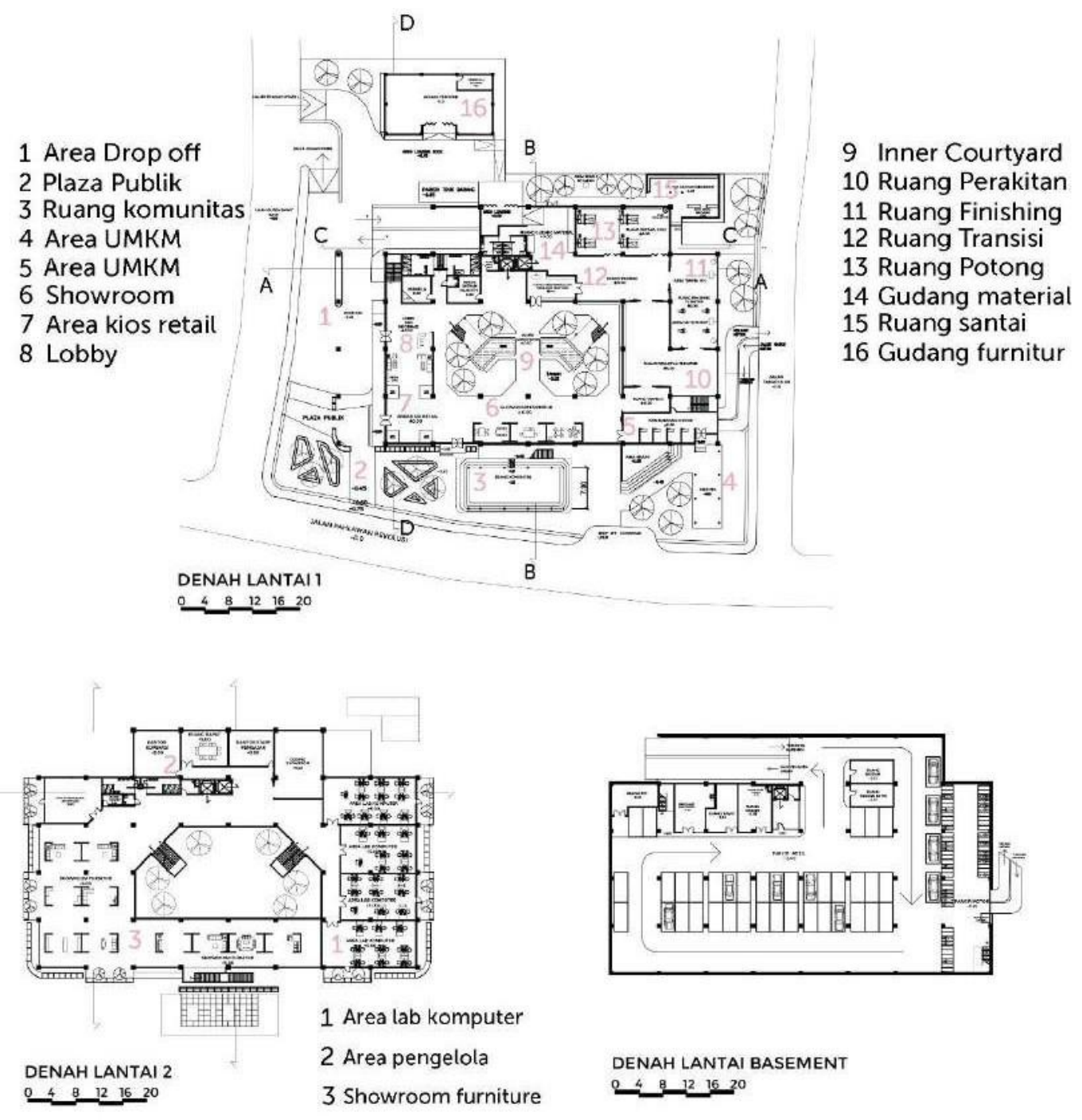

DENAH LANTAI BASEMENT -
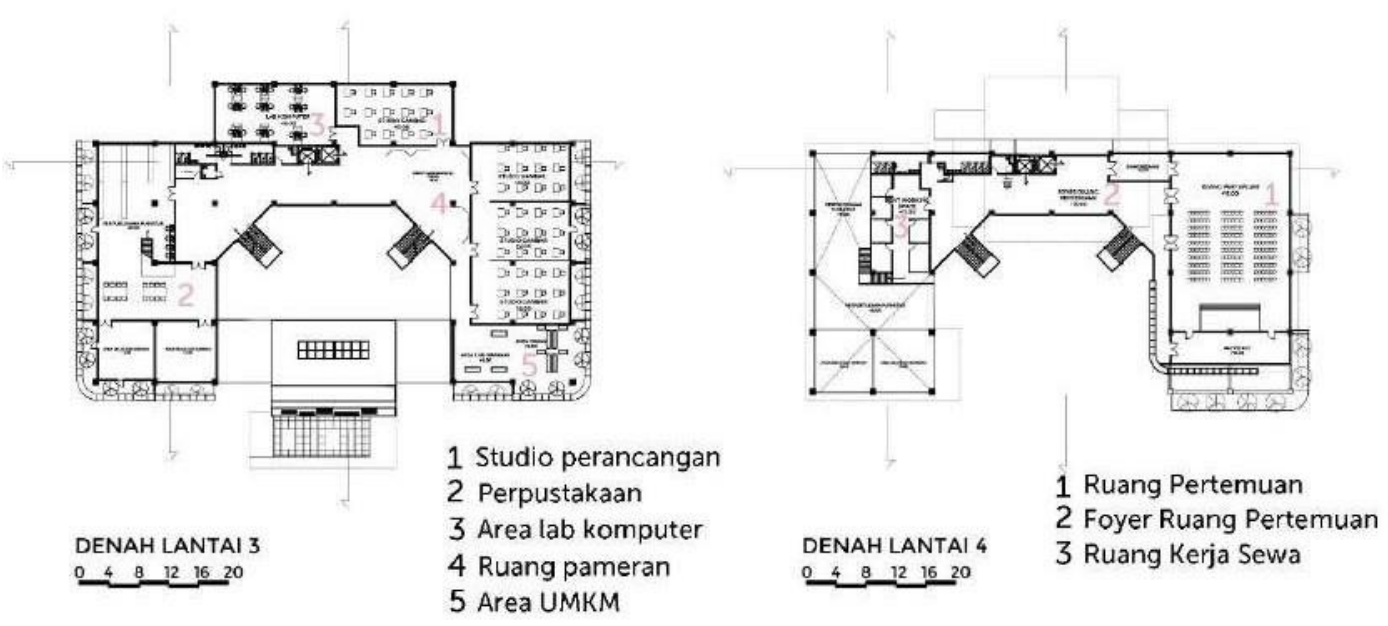

Gambar 11. Denah

Sumber : Penulis, 2020 


\section{Hubungan Ruang Luar dan Dalam}

Bagian ruang luar yang menghadap jalan utama, Jalan Pahlawan Revolusi merupakan ruang publik yang di desain untuk merangkul komunitas pengrajin furnitur dan menghidupkan aktivitas di kawasan. Ruang public ini terdiri dari plaza publik, ruang komunitas, dan area kios makanan UMKM. Untuk di bagian samping kiri tapak (yang menghadap Jalan Duren Sawit Raya, terdapat area sirkulasi kendaraan mobil dan loading untuk masuk ke tapak. Setelah itu, untuk bagian sisi kanan tapak digunakan untuk sirkulasi kendaraan motor.

\section{Ruang Dalam}

Perancangan ruang dalam di lantai dasar terbagi atas 2 zona, yaitu zona publik dan zona privat. Untuk zona publik terdapat ruang lobby dan informasi, area kios retail, dan showroom furniture. Untuk zona privat/pelatihan nya, terdapat ruang potong kayu, ruang finishing furnitur, ruang perakitan furnitur, ruang transisi untuk perpindahan barang, dan adanya ruang gudang material. Selain itu, terdapat juga inner courtyard di tengah-tengah massa bangunan untuk menjadi buffer antara area publik dan privat. Lantai 2 terbagi menjadi 3 zona, yaitu zona publik yang dirancang untuk mewadahi aktivitas pameran dengan adanya showroom furniture, zona privat yang mewadahi aktivitas pelatihan seperti lab komputer desain, zona pengelola. Lantai 3 dibagi menjadi 2 zona, yaitu zona publik dan pelatihan. Di zona publik terdapat ruang perpustakaan yang dapat diakses oleh publik. Lalu, untuk zona pelatihan terdapat ruang studio gambar furnitur dan lab komputer desain. Lantai 4 merupakan zona publik dengan adanya ruang pertemuan dan ruang kantor sewa yang merupakan mezzanine perpustakaan di bawahnya. Ruang pertemuan ini dudukung oleh ruang persiapan dan ruang backstage.

\section{Potongan Perspektif dan Detail Arsitektur}

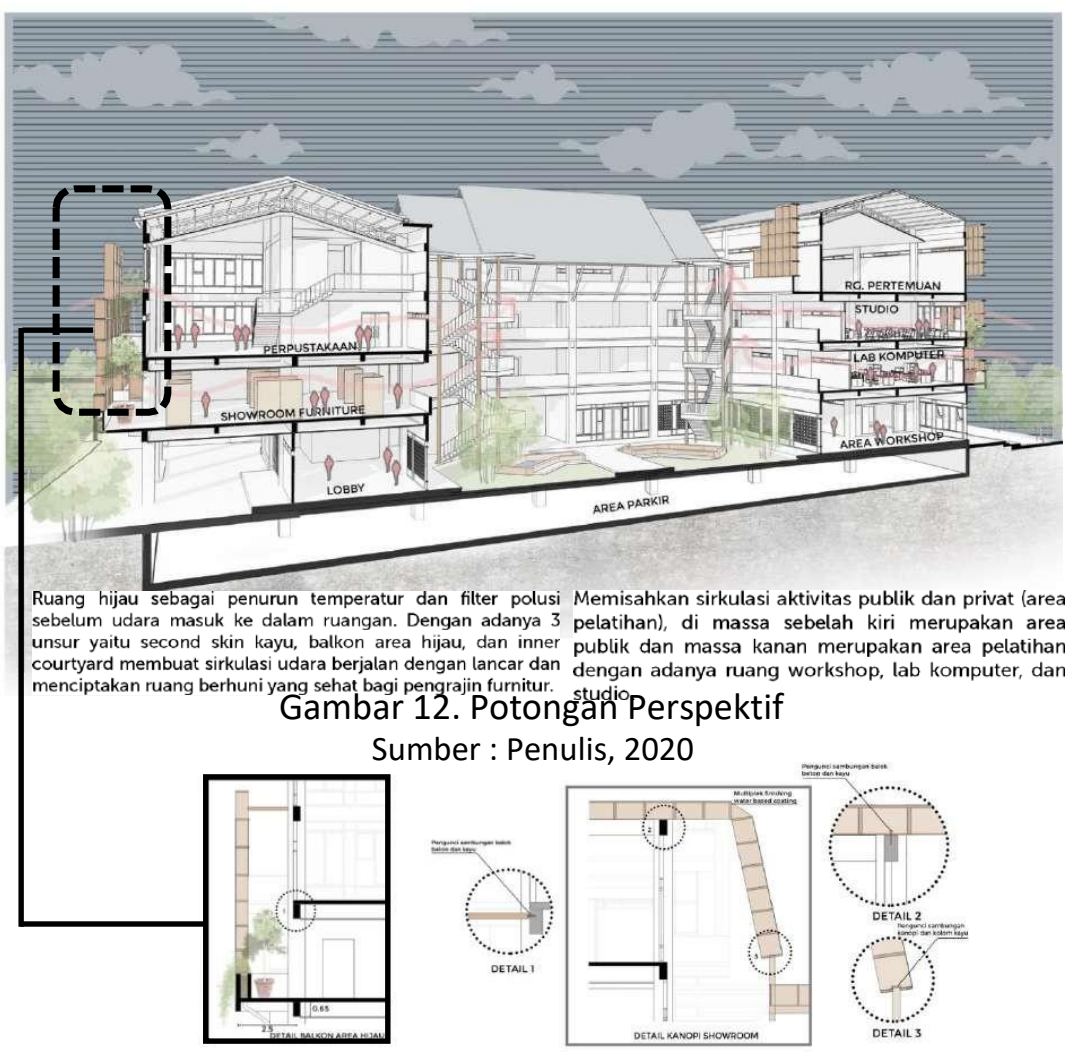

Gambar 13. Detail Arsitektur Sumber : Penulis, 2020 
Detail perancangan arsitektur berupa detail balkon area hijau dan detail kanopi showroom di desain dengan adanya sambungan antara material kayu dengan balok beton.

\section{Analisis Struktur}

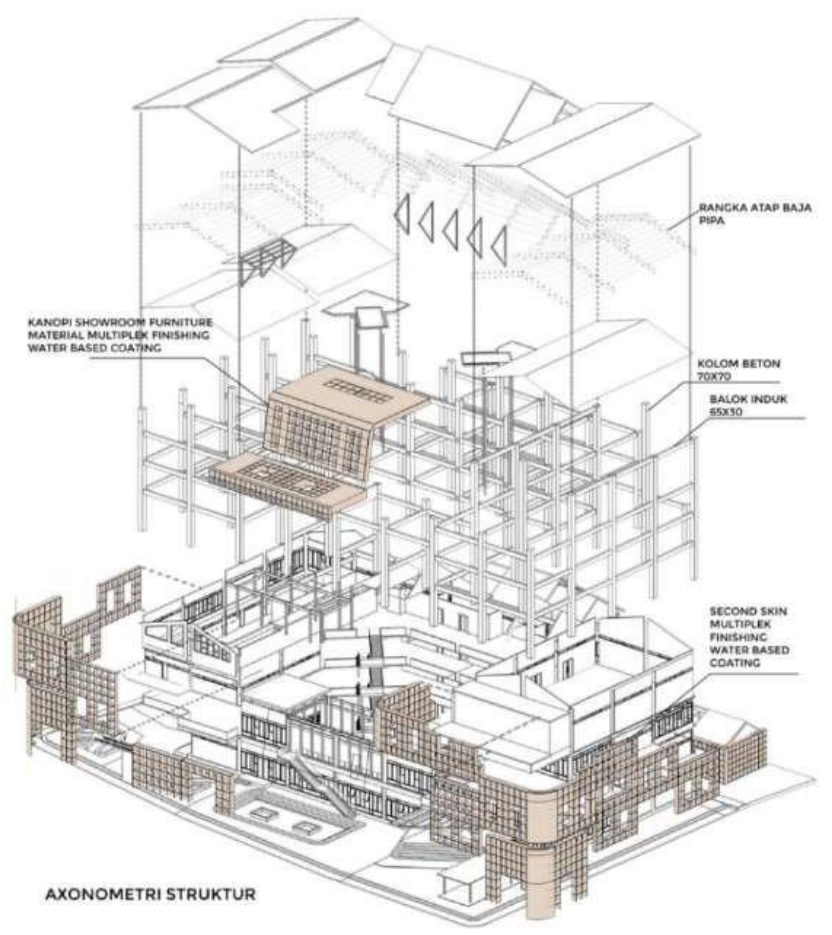

Gambar 14. Axonometri struktur Sumber : Penulis, 2020

Struktur utama dari bangunan ini adalah kolom beton $70 \times 70 \mathrm{~cm}$ dengan balok induk $65 \times 30$ $\mathrm{cm}$ dan balok anak $25 \times 50 \mathrm{~cm}$. Terdapat second skin bermaterialkan multiplek finishing water based coating untuk ketahanan cuaca yang memiliki sambungan dengan material beton pada balok induk sesuai dengan gambar detail. Struktur atap menggunakan struktur atap bentang lebar rangka bidang dengan material baja pipa berukuran 4" dan 2" untuk reng nya.

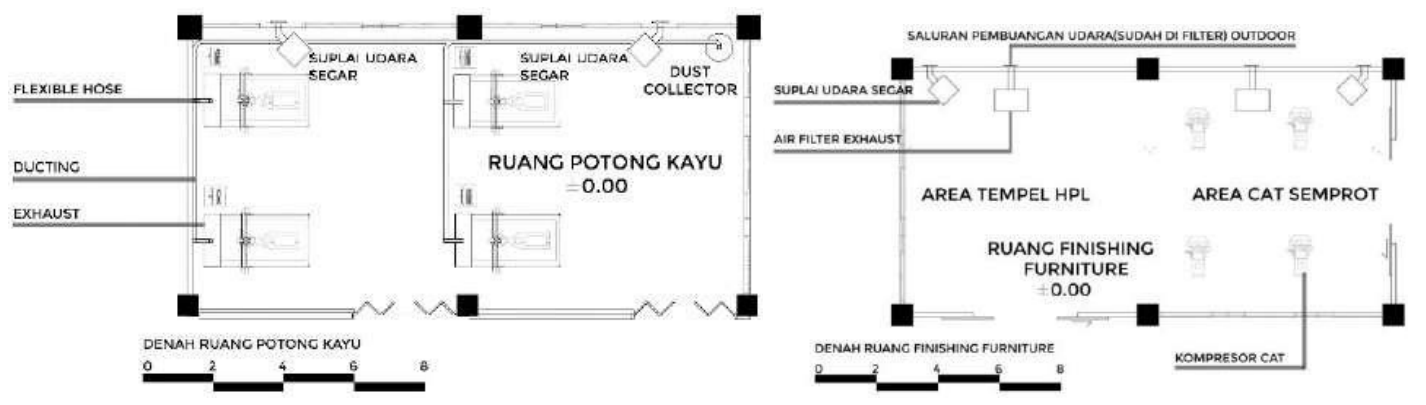

Gambar 15. Detail Ruang Potong dan Ruang Finishing Furnitur Sumber : Penulis, 2020 


\section{Detail Rancangan}

Dengan adanya sistem pengumpul debu dan serbuk kayu di ruang potong kayu serta sistem air filter di ruang finishing furnitur, kualitas lingkungan kerja para pengrajin menjadi lebih sehat.

\section{D Render}

\section{Perspektif Eksterior dan Interior}

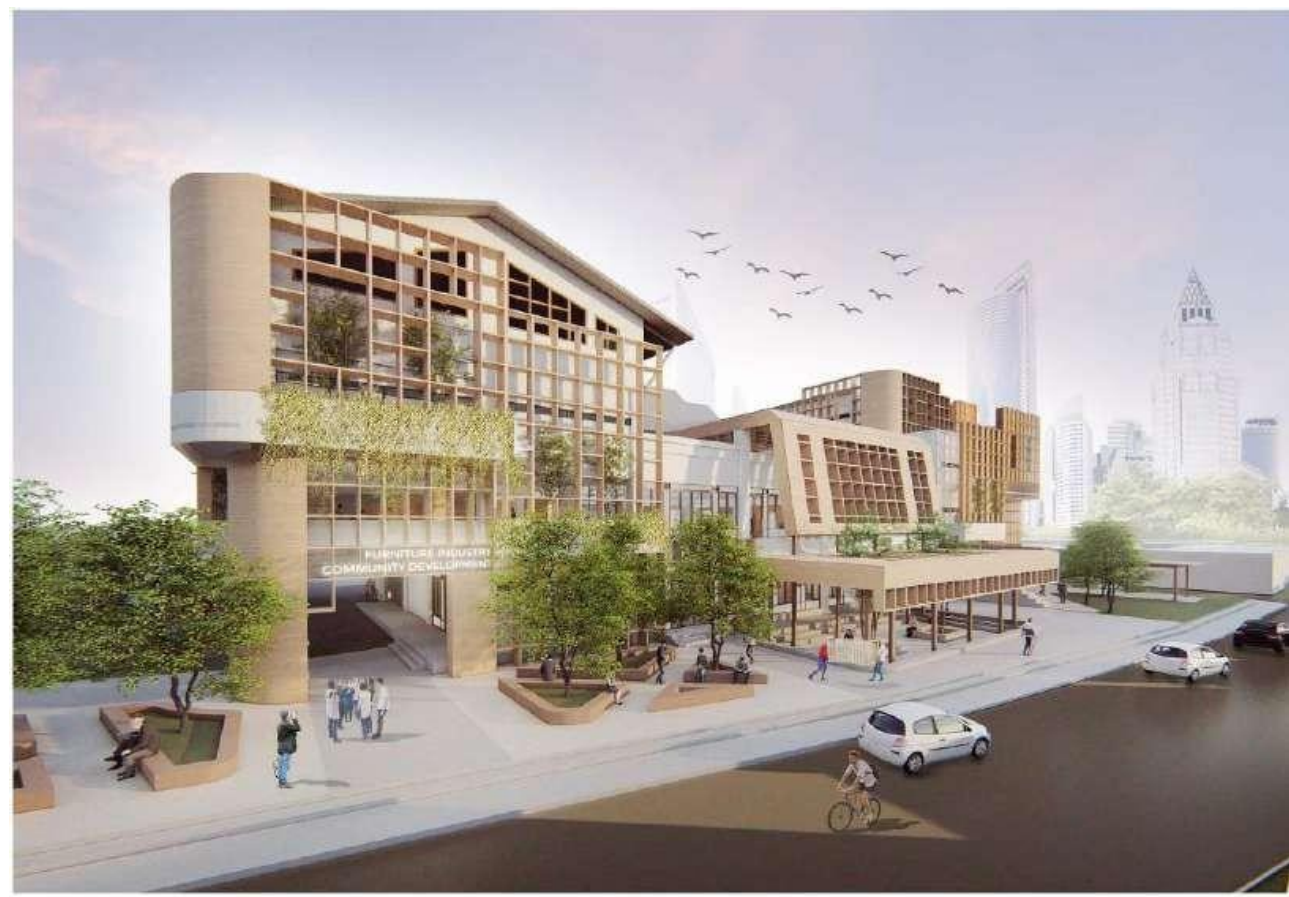

PERSPEKTIF EKSTERIOR

Gambar 16. Perspektif eksterior

Sumber : Penulis, 2020
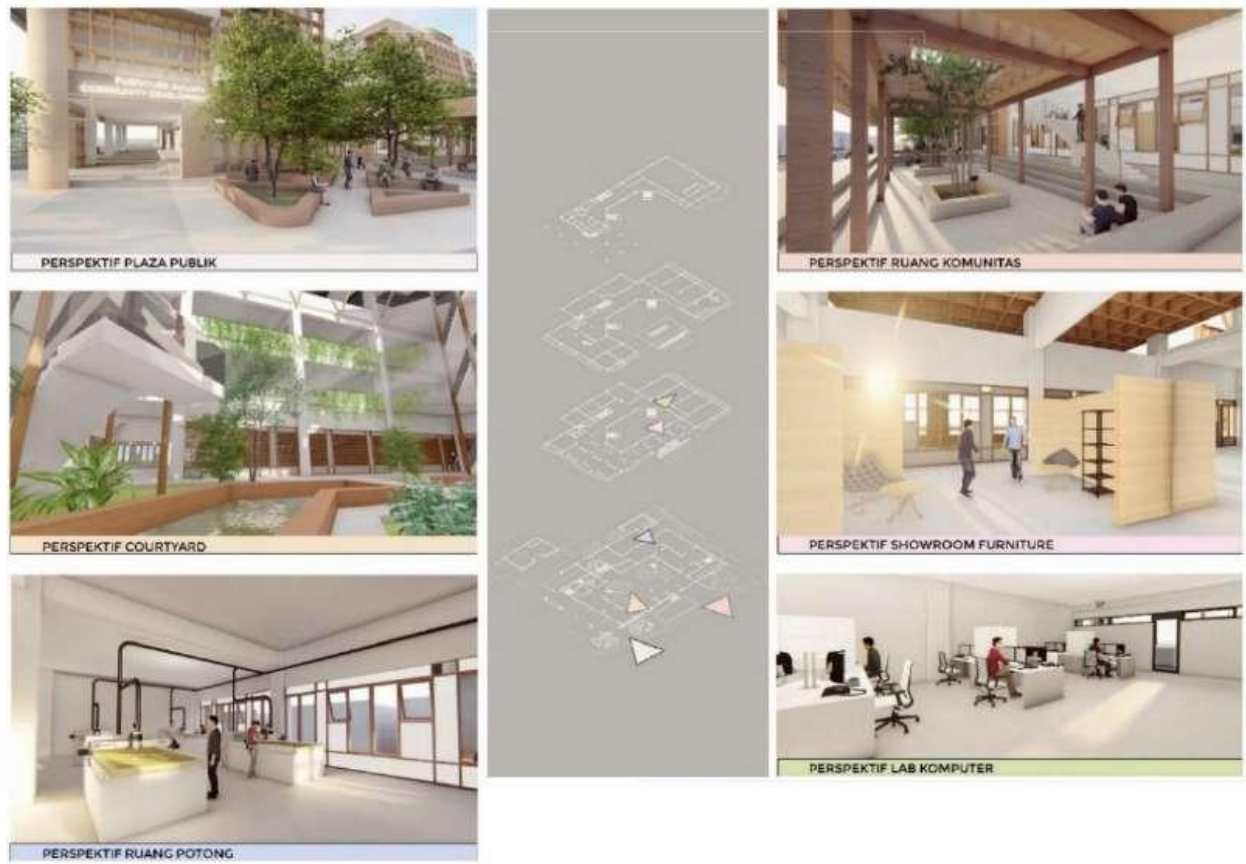

Gambar 17. Perspektif interior

Sumber : Penulis, 2020 


\section{KESIMPULAN DAN SARAN}

\section{Kesimpulan}

Berdasarkan isu akan kurangya teknologi, promosi, dan kesehatan lingkungan kerja pada industri furnitur kecil dan menengah, maka menghasilkan sintesis berupa program-program ruang yang menjawab tuntutan industri furnitur modern dengan pelatihan industri yang bersistem knockdown. Metode perancangan dari proyek ini menggunakan pendekatan pragmatis dengan fokus menciptakan lingkungan kerja yang sehat dan nyaman untuk dihuni berdasarkan desain program ruangnya. Pendekatan pragmatis ini diterjemahkan melalui desain sirkulasi udara yang baik pada bangunan dengan adanya balkon area hijau dan inner courtyard. Selain itu menciptakan sistem pengumpul debu dan filter udara pada ruang-ruang produksi untuk kesehatan pengrajin. Sektor promosi dikembangkan dengan adanya showroom furniture yang layak dan menciptakan ruang- ruang publik untuk menarik pengunjung. Lalu, menciptakan wadah aktivitas bagi komunitas pengrajin furnitur. Proyek perancangan ini bertujuan untuk memberikan sumbangsih bagi ilmu arsitektur berupa desain percontohan untuk perancangan lingkungan kerja pengrajin furnitur yang sehat untuk ke depannya. Tentunya, proyek ini juga bertujuan untuk kemajuan industri furnitur kecil dan menengah Klender supaya dapat bersaing dan unggul, serta memiliki lingkungan kerja yang sehat bagi pengrajin.

\section{REFERENSI}

Anupama, S., Dhote, K. (2003). Climatic Responsive Energy Efficient Passive Techniques in Building. Bhopal : Maulana Azad National Institute of Technology.

Certeau, M. (1998). The Practice of Everyday Life. Minnesota: The Regents of the University of Minnesota.

Christina, N., Yong, S., Basuki, L. (2019). Perancangan Interior Sentra Galeri dan Workshop Kerajinan Kayu di Blora, Jawa Tengah. Surabaya : Program Studi Desain Interior, Universitas Kristen Petra.

Heidegger, M. (1971). Building Dwelling Thinking. New York: Harper Colophon Books.

Nur, E. (2011). Klaster Industri Mebel Klender. Fakultas Matematika dan Ilmu Alam Universitas Indonesia.

Stefanny, M. Indrayani, R. (2013). Pengelolaan dan Pengembangan Usaha Furniture pada Aspek Pemasaran CV. Megahtama Cemerlang. Surabaya: Program Manajemen Bisnis, Program Studi Manajemen, Universitas Kristen Petra.

Stone, A., Carr, S., Francism, M., Rivlin, L. (1992). Public Space. Cambridge: Cambridge University Press.

Wijayanti, Dika Novi. Utomo, Tri Noviyanto. Susan, Maria Yohana. Perancangan Furnitur Serta Fasilitas Pendukungnya dengan Menggunakan Material Ramah Lingkungan. (2017). Surabaya: Arsitektur Interior, Universitas Ciputra.

Furniture Cetakan 3d Akan Banjiri Rumah Masa Depan, fomustudio.com, diakses tanggal 14 September 2020, https://fomustudio.com/furnitur-cetakan-3d-design-akan-banjirirumah-masa-depan/

Alur Proses Pembuatan Furnitur, klikteknik.com, diakses tanggal 18 September 2020, https://www.klikteknik.com/blog/alur-proses-pembuatan-furniture.html 